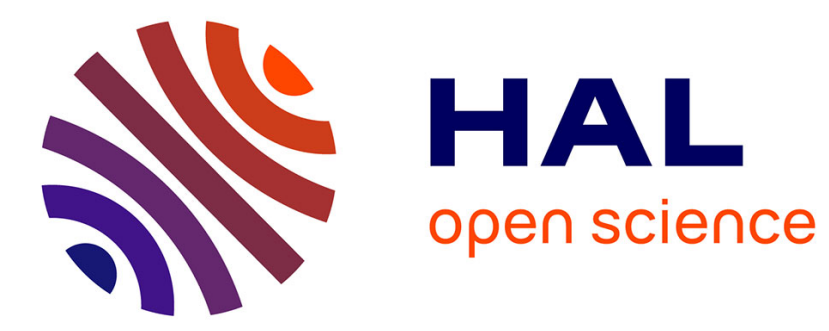

\title{
Towards anode with low indium content as effective anode in organic solar cells
}

\author{
S Touihri, Linda Cattin, Duc-Tuong Nguyen, M Morsli, Guy Louarn, Anne \\ Bouteville, Vincent Froger, Jean-Christian Bernède
}

\section{- To cite this version:}

S Touihri, Linda Cattin, Duc-Tuong Nguyen, M Morsli, Guy Louarn, et al.. Towards anode with low indium content as effective anode in organic solar cells. Applied Surface Science, 2012, 258 (7), pp.2844-2849. hal-01061935

\section{HAL Id: hal-01061935 \\ https://hal.science/hal-01061935}

Submitted on 8 Sep 2014

HAL is a multi-disciplinary open access archive for the deposit and dissemination of scientific research documents, whether they are published or not. The documents may come from teaching and research institutions in France or abroad, or from public or private research centers.
L'archive ouverte pluridisciplinaire HAL, est destinée au dépôt et à la diffusion de documents scientifiques de niveau recherche, publiés ou non, émanant des établissements d'enseignement et de recherche français ou étrangers, des laboratoires publics ou privés. 


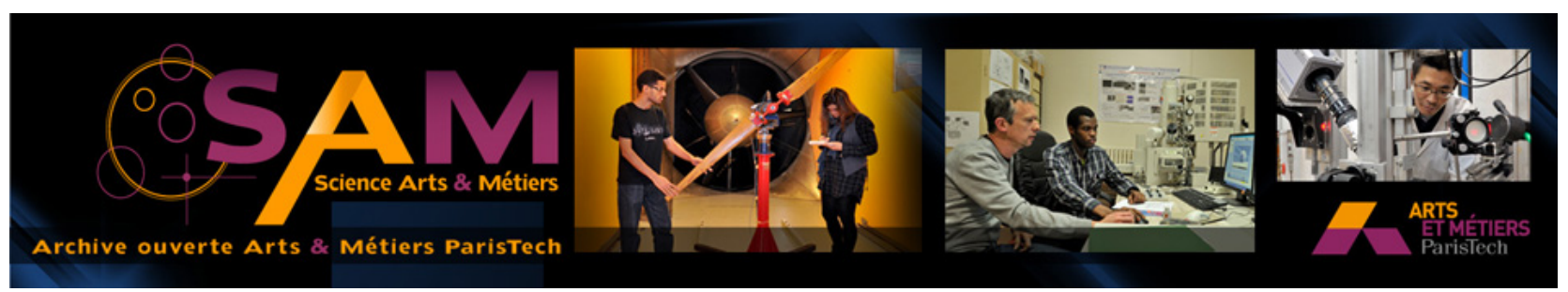

\section{Science Arts \& Métiers (SAM)}

is an open access repository that collects the work of Arts et Métiers ParisTech researchers and makes it freely available over the web where possible.

This is an author-deposited version published in: http://sam.ensam.eu

Handle ID: .http://hdl.handle.net/10985/8483

\section{To cite this version :}

S TOUIHRI, Linda CATTIN, Duc-Tuong NGUYEN, M MORSLI, Guy LOUARN, Anne BOUTEVILLE, Vincent FROGER, Jean-Christian BERNĖDE - Towards anode with low indium content as effective anode in organic solar cells - Applied Surface Science - Vol. 258, $n^{\circ} 7$, p.2844-2849 - 2012 


\title{
Towards anode with low indium content as effective anode in organic solar cells
}

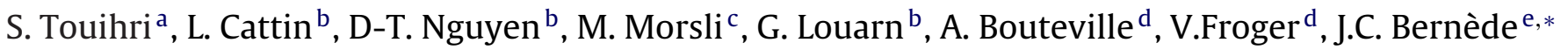 \\ a Unité de Physique des Dispositifs à Semi-conducteurs, Université El Manar Faculté des Sciences de Tunis, Campus Universitaire 2092, Tunisia \\ ${ }^{b}$ LUNAM, Université de Nantes, Institut Jean Rouxel (IMN), UMR 6502, 2 rue de la Houssinière, BP 92208, Nantes F-44322, France \\ ' LUNAM, Université de Nantes, Faculté des Sciences et des Techniques, 2 rue de la Houssinière, BP 92208, Nantes F-44322, France \\ ${ }^{\mathrm{d}}$ Arts et Métiers Paris Tech Angers, Laboratoire Procédés-Matériaux-Instrumentation, 2, bd du Ronceray, BP 3525, 49035 Angers Cedex, France \\ e LUNAM, Université de Nantes, Moltech Anjou, CNRS, UMR 6200, FSTN, 2 Rue de la Houssinière, BP 92208, Nantes F-44322, France
}

Keywords:

Organic solar cell

Reactive evaporation

$\operatorname{In}_{2} \mathrm{O}_{3}$

Surface roughness

Surface work function

\begin{abstract}
A B S T R A C T
$\mathrm{In}_{2} \mathrm{O}_{3}$ thin films ( $100 \mathrm{~nm}$ thick) have been deposited by reactive evaporation of indium, in an oxygen partial atmosphere. Conductive $\left(\sigma=3.5 \times 10^{3} \mathrm{~S} / \mathrm{cm}\right)$ and transparent films are obtained using the following experimental conditions: oxygen partial pressure $=1 \times 10^{-1} \mathrm{~Pa}$, substrate temperature $=300^{\circ} \mathrm{C}$ and deposition rate $=0.02 \mathrm{~nm} / \mathrm{s}$. Layers of this $\mathrm{In}_{2} \mathrm{O}_{3}$ thick of $5 \mathrm{~nm}$ have been introduced in $\mathrm{AZO} / \mathrm{In}_{2} \mathrm{O}_{3}$ and $\mathrm{FTO} / \mathrm{In}_{2} \mathrm{O}_{3}$ multilayer anode structures. The performances of organic photovoltaic cells, based on the couple $\mathrm{CuPc} / \mathrm{C}_{60}$, are studied using the anode as parameter. In addition to these bilayers, other structures have been used as anode: $\mathrm{AZO}, \mathrm{FTO}, \mathrm{AZO} / \mathrm{In}_{2} \mathrm{O}_{3} / \mathrm{MoO}_{3}, \mathrm{FTO} / \mathrm{In}_{2} \mathrm{O}_{3} / \mathrm{MoO}_{3}$ and $\mathrm{FTO} / \mathrm{MoO}_{3}$. It is shown that the use of the $\mathrm{In}_{2} \mathrm{O}_{3}$ film in the bilayer structures improves significantly the cell performances. However the open circuit voltage is quite small while better efficiencies are achieved when $\mathrm{MoO}_{3}$ is present. These results are discussed in the light of surface roughness and surface work function of the different anodes.
\end{abstract}

\section{Introduction}

Organic solar cells are attracting considerable interest for solar energy conversion. Organic photovoltaic cells (OPV) are based on a couple electron donor (ED)/electron acceptor (EA). Two OPV families have been developed depending on the ED/EA interface geometry, the planar heterojunction (PHJ) and the bulk heterojunction (BHJ). PHJ are based on the superposition of thin films of donor and acceptor materials, while in BHJ the active layer constitutes of interpenetrated networks of the two organic materials (ED and EA). Whatever the cell family type is, the organic layers are sandwiched between two electrodes, one of them, at least, must be transparent [1].

Until now, most OPV incorporated tin doped indium oxide (ITO) as transparent electrode. ITO is highly conductive $\left(\sigma>10^{3} \mathrm{~S} / \mathrm{cm}\right)$ with a good transparency $(T>90 \%)$ in the visible range. Moreover its work function, $\Phi_{\text {ITO }}$, is higher than that of others transparent conductive oxide (TCO). $\Phi_{\text {ITO }}$ is around $4.6 \pm 0.2 \mathrm{eV}$ after cleaning of commercial ITO [2-4]. This latter can be increased by some treatment such as UV-ozone plasma [5]. Also, the $\Phi_{\text {ITO }}$ can be higher than the classical value if the ITO layer is used immediately after deposition. For instance, when deposited by RF magnetron sputtering, $\Phi_{\text {ITO }}$ can be as high as $5.5 \mathrm{eV}$ [6]. However, indium is

\footnotetext{
* Corresponding author.

E-mail address: jean-christian.bernede@univ-nantes.fr (J.C. Bernède).
}

scarce and the price of ITO is increasing due to a high demand in a large variety of applications. Therefore it would be very attractive to use other transparent electrode [7]. If others TCO, such as aluminium doped zinc oxide (AZO) or fluorine doped tin oxide (FTO) can show electrical and optical properties close to that of ITO, their work functions are substantially smaller [8,9]. To address the question of whether it can be possible to keep the surface properties of ITO through smaller indium consumption, we have probed $\mathrm{AZO} / \mathrm{In}_{2} \mathrm{O}_{3}$ and $\mathrm{FTO} / \mathrm{In}_{2} \mathrm{O}_{3}$ bilayer structures, in the thickness ratio $t_{\mathrm{In}_{2} \mathrm{O}_{3}} / t_{\mathrm{TCO}}=1 / 20$, as an alternative to ITO anode in classical OPV. After characterization of the different TCO thin films, the properties of the bilayer structures have been probed and then used as anode in OPV. For comparison, different anode configurations have also been probed: $\mathrm{TCO} / \mathrm{MoO}_{3}, \mathrm{TCO} / \mathrm{In}_{2} \mathrm{O}_{3} / \mathrm{MoO}_{3}$.

\section{Experimental}

\subsection{Deposition process and characterization techniques of the TCO thin films}

FTO films have been provided by SOLEMS, while the AZO and $\mathrm{In}_{2} \mathrm{O}_{3}$ films have been deposited in the laboratory. The FTO films have been obtained by chemical vapour deposition, while the AZO films have been deposited by rf magnetron sputtering. The deposition process of the zinc oxide films has been described in a previous paper [10]. Shortly, they were deposited by ac magnetron sputtering on glass substrates at room temperature. The cylindrical $\mathrm{ZnO}$ 
target contains 2 wt\% of $\mathrm{Al}_{2} \mathrm{O}_{3}$. Ar was used as sputtering gas for deposition of the AZO films. The sputtering pressure was maintained at $0.13 \mathrm{~Pa}$. The pressure of the sputtering system before the deposition of the sample films was under $2 \times 10^{-3} \mathrm{~Pa}$.

$\mathrm{In}_{2} \mathrm{O}_{3}$ thin films were deposited by reactive evaporation of indium, in an oxygen partial atmosphere, onto glass substrate. The films were elaborated in a vacuum chamber from an Indium source with resistively heated tungsten crucible source. During deposition the substrates were heated at $300^{\circ} \mathrm{C}$. They were heated by an infrared source. The temperature of the substrate was determined by a thermocouple (type $\mathrm{K}$ ) on the deposition face. Before deposition the vacuum in the deposition chamber was $5 \times 10^{-4} \mathrm{~Pa}$, during deposition, the flow rate of oxygen was controlled by using a flow meter. The deposition pressure was maintained at $1 \times 10^{-1} \mathrm{~Pa}$. An HF quartz oscillator was used to control the evaporation rate. To be sure to achieve complete indium oxidation at $300^{\circ} \mathrm{C}$, the deposition rate was $0.02 \mathrm{~nm} / \mathrm{s}$. Before probing the $\mathrm{In}_{2} \mathrm{O}_{3}$ in anode bilayers in OPV, we have deposited $100 \mathrm{~nm}$ thick film to check the optical and electrical properties of our $\mathrm{In}_{2} \mathrm{O}_{3}$ thin films.

The crystalline structure of the films was analyzed by X-ray diffraction (XRD) by a Siemens D 5000 diffractometer using K $\alpha$ radiation from $\mathrm{Cu}(\lambda=0.15406 \mathrm{~nm})$. The morphology was observed through scanning electron microscopy (SEM) with a JEOL 6400F. The films thickness was measured from the cross section visualization using simple software. The composition of the films was checked by electron microprobe analysis (EMPA) using a JEOL 5800 microscope.

XPS analyses were performed with a Leybold LHS-12 apparatus. The data were obtained with a magnesium source of radiation $(1253.6 \mathrm{eV})$ operating at $10 \mathrm{kV}$ and $10 \mathrm{~mA}$. The energy resolution was $1 \mathrm{eV}$ at pass energy of $50 \mathrm{eV}$. High-resolution scans were obtained in the In $3 \mathrm{~d}, \mathrm{O} 1 \mathrm{~s}$ and also $\mathrm{C} 1 \mathrm{~s}$ regions of the spectrum. The quantitative XPS studies were based on the determination of the $\operatorname{In} \mathrm{d}_{5 / 2}$ and $01 \mathrm{~s}$ peak areas with 3.8 and 0.61 as sensitivity factors, (the sensitivity factors are given by the manufacturer, Leybold).

The optical measurements were carried out at room temperature on a Carry spectrometer, from 2 to $0.20 \mu \mathrm{m}$ wavelengths.The four-points probe technique has been used to measure the electrical conductivity. Hall effect measurements were performed utilizing the Van der Paw arrangement.

AFM images on different sites of the films were taken at atmospheric pressure and room temperature. All measurements were performed in tapping mode (Nanoscope IIIa, (Veeco, Inc.). Classical silicon cantilevers were used ( $\mathrm{NCH}$, nanosensors). The average force constant and resonance were $40 \mathrm{~N} / \mathrm{m}$ and $300 \mathrm{kHz}$, respectively. The cantilever was excited at its resonance frequency. Such apparatus can also be managed as electrostatic force microscope, which allows using it as surface Kelvin probe microscope.

A Kruss G40 Contact Angle Measuring System G40 is used to estimate the surface energy of TCO surfaces through the sessile drop method. A drop of liquid with known surface tension (water, formamide, ethylene glycol and glycerol) is put on the TCO surface and according to the Owens, Wendt, Rabel and Kaelble method, the surface tension, split up into a polar and a disperse fraction, can be deduced.

\subsection{Organic solar cells realization and characterization}

This work deals with the influence of the anode configuration on organic solar cells performance. Therefore, an already known multilayers heterojunction structure based on a $\mathrm{CuPc} / \mathrm{C}_{60}$ junction with bathocuproine (BCP) as electron blocking layer was chosen.

CuPc donor and $\mathrm{C}_{60}$ acceptor organic materials are commercially available and were purified by vacuum sublimation [11]. All the results presented in figures or tables have been attained with cells issued from the same baths of products.

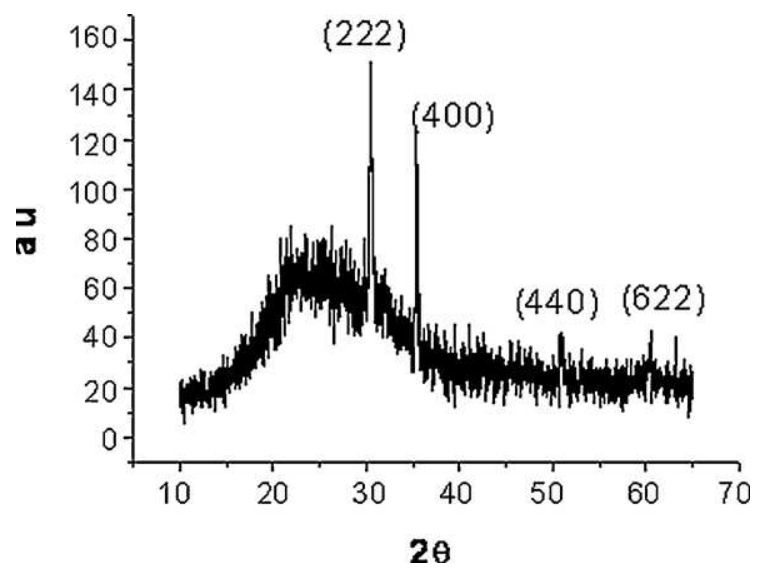

Fig. 1. X-ray diffraction diagram of a $\operatorname{In}_{2} \mathrm{O}_{3}$ thin film achieved by reactive evaporation.

CuPc, $\mathrm{C}_{60}$ and BCP were deposited under $10^{-4}$ Pa vacuum. The thin film deposition rate and thickness were estimated in situ by the quartz monitor. The deposition rate and final thickness were respectively $0.05 \mathrm{~nm} / \mathrm{s}$ and $35 \mathrm{~nm}$ for CuPc and $0.05 \mathrm{~nm} / \mathrm{s}$ and $40 \mathrm{~nm}$ for $\mathrm{C}_{60}$, while they were $0.1 \mathrm{~nm} / \mathrm{s}$ and $9 \mathrm{~nm}$ for BCP.

After organic thin film deposition, without breaking the vacuum, an aluminium upper electrode, through a mask with $2 \mathrm{~mm} \times 5 \mathrm{~mm}$ active area, and then an encapsulating layer of amorphous selenium (Se-a), thick of about $100 \mathrm{~nm}$, were thermally evaporated.

The selenium coating layer has been proved to be efficient to protect the under layers from oxygen and water vapour contamination [12], at least during the first hours of room air exposure [13]. The used structures were as follows: glass/anode structure $/ \mathrm{CuPc} / \mathrm{C}_{60} / \mathrm{BCP} / \mathrm{Al} / \mathrm{Se}-\mathrm{a}$.

The different anode structures will be described in Section 3.

Electrical characterization was performed on an automated $I-V$ tester, in the dark and under 1 sun global AM 1.5 calibrated solar simulator (Oriel $300 \mathrm{~W}$ ) at $100 \mathrm{~mW} / \mathrm{cm}^{2}$ light intensity adjusted with a photovolatic reference cell $\left(0.5 \mathrm{~cm}^{2} \mathrm{Cu}(\mathrm{InGa}) \mathrm{Se}_{2}\right.$ solar cell, calibrated at NREL, USA. Measurements were performed at normal room atmosphere. All devices were illuminated through FTO electrodes.

\section{Experimental results and discussion}

\section{1. $\mathrm{In}_{2} \mathrm{O}_{3}$ thin film characterization}

The thicknesses of the films used were $100 \mathrm{~nm}$ for $\operatorname{In}_{2} \mathrm{O}_{3}$ thin film characterization and $100 \mathrm{~nm}$ for the TCO (AZO or FTO) and $5 \mathrm{~nm}$ for the $\mathrm{In}_{2} \mathrm{O}_{3}$ in the case of anode bilayer TCO/ $/ \mathrm{In}_{2} \mathrm{O}_{3}$.

As shown by XRD in Fig. 1, the films are polycrystalline. They are crystallised in the expected bixbyite structure. The crystallites are preferentially oriented along the [2 22 ] and [4 00 0] directions. A typical micrograph of the films obtained is presented in Fig. 2a. The films are granular, which is in good agreement to the XRD study. They are homogeneous and compact. For comparison, in Fig. $2 \mathrm{~b}$ and c are visualized FTO and FTO/ $\mathrm{In}_{2} \mathrm{O}_{3}$ films. It can be seen in Fig. 2, that, all the structures are polycrystalline with similar averaged grain diameter of around $65 \mathrm{~nm}$. The microprobe analysis shows that the films are stoichiometric. The level of accuracy of the method does not allow putting directly in evidence the oxygen vacancy density.

For XPS study, the samples had to stay in air from the depositing chamber to the analysis apparatus, therefore they have been gently etched before analysis. If some surface contamination is still present, the quantitative analysis shows that the surface of the films is nearly stoichiometric (around 60 at.\% of oxygen), while it can be seen in Fig. 3a that the main 01s contribution is 

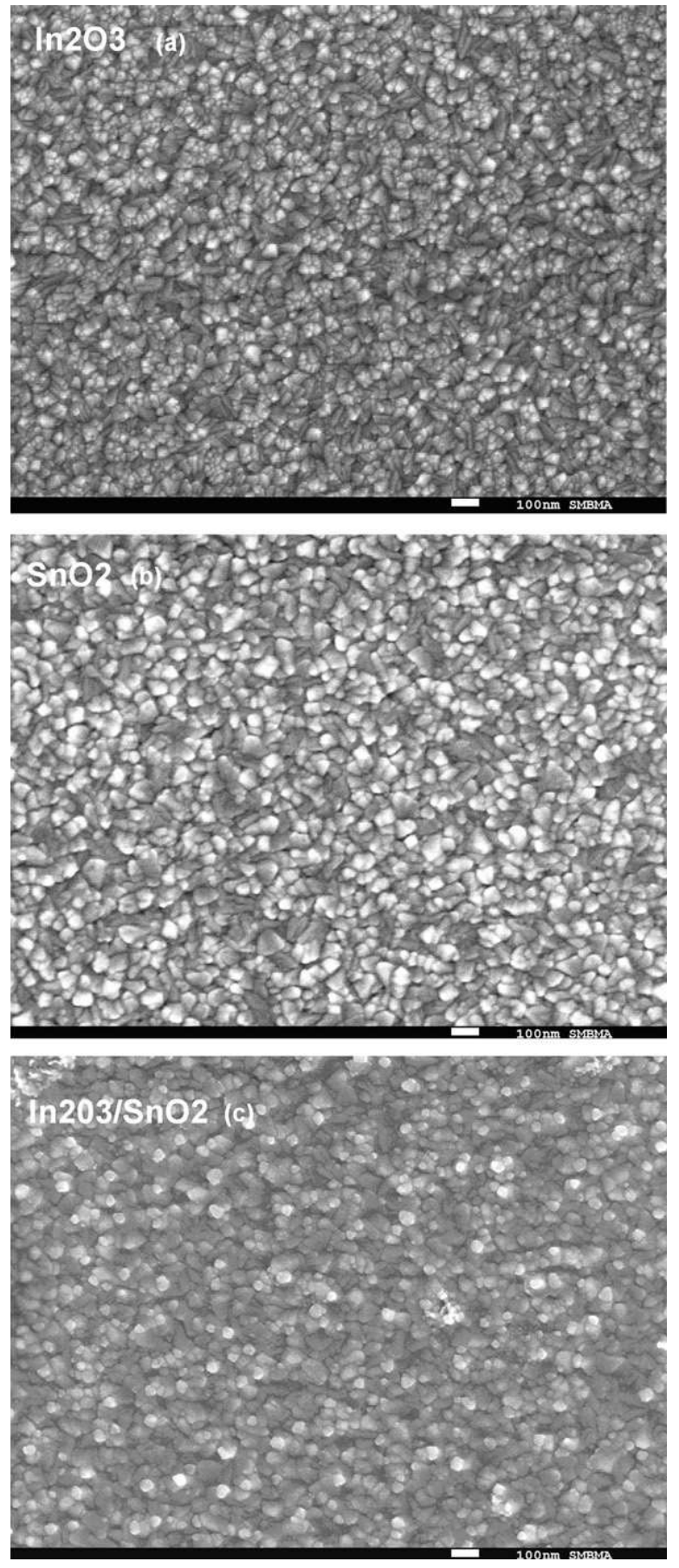

Fig. 2. Microphotographs of an ITO (a), a $\mathrm{SnO}_{2}$ (b) and a $\mathrm{SnO}_{2} / \mathrm{ITO}$ (3) structure.

situated at $530.3 \mathrm{eV}$, which corresponds to oxygen bounded to indium. The second contribution, only $15 \%$, is situated at $532.6 \mathrm{eV}$. It can be attributed to surface contamination. The In3d doublet (Fig. 3b), with In $3 \mathrm{~d}_{5 / 2}=444.5 \mathrm{eV}$ and In $3 \mathrm{~d}_{3 / 2}=452 \mathrm{eV}$, corresponds to indium bounded to oxygen [14]. The spectrum in Fig. 4 shows that transmission of a film in the visible and near infrared is higher than $80 \%$ up to $95 \%$ for $\lambda \approx 1100 \mathrm{~nm}$. At room temperature, the conductivity of the films is $3.5 \times 10^{3} \mathrm{~S} / \mathrm{cm}$ with a carrier mobility of $10.5 \mathrm{~cm}^{2} \mathrm{~V}^{-1} \mathrm{~s}^{-1}$ and a carrier density of $1.4 \times 10^{21} \mathrm{~cm}^{-3}$.

All these studies show that the $\mathrm{In}_{2} \mathrm{O}_{3}$ films obtained by reactive evaporation exhibit the properties requested for a TCO. Therefore they can be introduced in an anode bilayer such as $\mathrm{AZO} / \mathrm{In}_{2} \mathrm{O}_{3}$ or $\mathrm{FTO} / \mathrm{In}_{2} \mathrm{O}_{3}$.
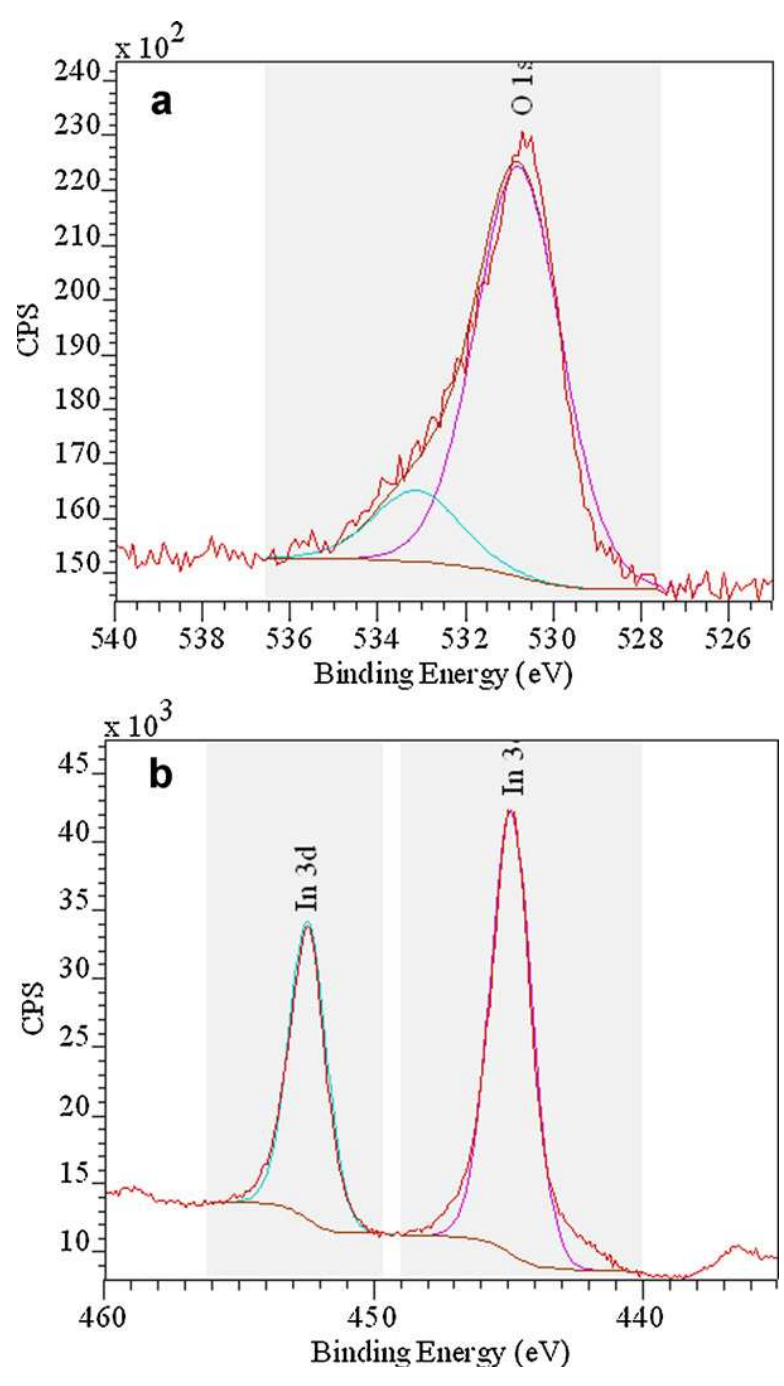

Fig. 3. $\mathrm{In}_{2} \mathrm{O}_{3}$ XPS spectra of an $\operatorname{In}_{2} \mathrm{O}_{3}$ thin film, O1s (a) and In3d (b).

3.2. Organic photovoltaic cells using $\mathrm{AZO} / \mathrm{In}_{2} \mathrm{O}_{3}$ and $\mathrm{FTO} / \mathrm{In}_{2} \mathrm{O}_{3}$ anodes

As said above the OPV cells studied were typically: glass/anode structure $/ \mathrm{CuPc} / \mathrm{C}_{60} / \mathrm{BCP} / \mathrm{Al} / \mathrm{Se}-\mathrm{a}$.

The anode structures probed were: $\mathrm{AZO}, \mathrm{AZO} / \mathrm{In}_{2} \mathrm{O}_{3}$, $\mathrm{AZO} / \mathrm{In}_{2} \mathrm{O}_{3} / \mathrm{MoO}_{3}$ and FTO, FTO $/ \mathrm{In}_{2} \mathrm{O}_{3}, \mathrm{FTO} / \mathrm{In}_{2} \mathrm{O}_{3} / \mathrm{MoO}_{3} . \mathrm{MoO}_{3}$

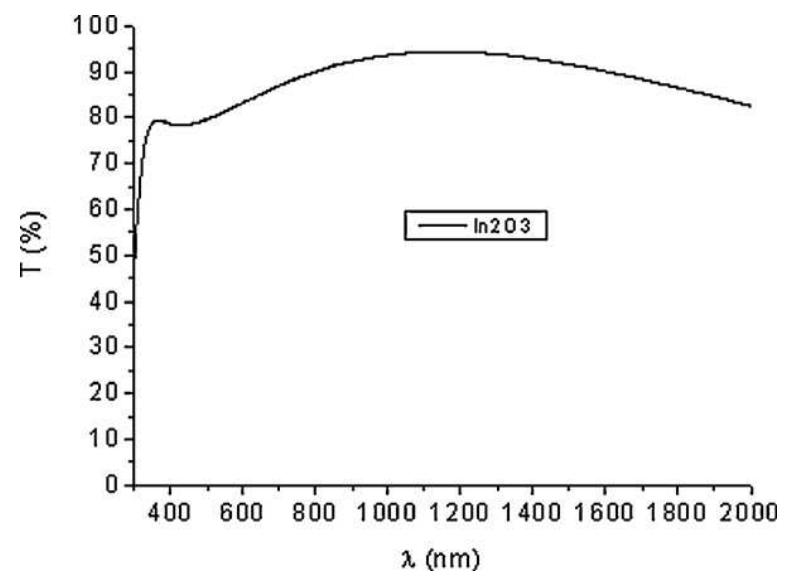

Fig. 4. Variation of the transmittance of an ITO film (100 nm). 
Table 1

Photovoltaic performance data under AM1.5 conditions of OPV cells using different anodes.

\begin{tabular}{lllll}
\hline Anode & $J_{\text {sc }}\left(\mathrm{mA} / \mathrm{cm}^{2}\right)$ & $V_{\text {oc }}(\mathrm{V})$ & $\mathrm{FF}(\%)$ & $\eta(\%)$ \\
\hline $\mathrm{AZO}$ & 2.85 & 0.22 & 15 & 0.10 \\
$\mathrm{AZO} / \mathrm{In}_{2} \mathrm{O}_{3}$ & 5.50 & 0.28 & 51 & 0.77 \\
$\mathrm{AZO} / \mathrm{In}_{2} \mathrm{O}_{3} / \mathrm{MoO}_{3}$ & 8.70 & 0.43 & 53 & 1.95 \\
$\mathrm{FTO}$ & 3.50 & 0.30 & 15 & 0.15 \\
$\mathrm{FTO} / \mathrm{In}_{2} \mathrm{O}_{3}$ & 6.50 & 0.25 & 25 & 0.40 \\
$\mathrm{FTO} / \mathrm{In}_{2} \mathrm{O}_{3} / \mathrm{MoO}_{3}$ & 6.60 & 0.43 & 50 & 1.42 \\
$\mathrm{FTO} / \mathrm{MoO}_{3}$ & 6.50 & 0.45 & 50 & 1.45 \\
\hline
\end{tabular}

has been used as buffer layer between the anode and the organic electron donor since it has been shown that it is very efficient in improving the hole collection and OPV cells performances [15].

It can be seen in Table 1 and Fig. 5 that, whatever the TCO used, AZO or FTO, the OPV cells performances are significantly improved when the TCO is covered with a thin $\operatorname{In}_{2} \mathrm{O}_{3}$ layer, thick of $5 \mathrm{~nm}$. This improvement corresponds to an increase of the fill factor and short circuit current. It should also be noted that, in the case of bare TCO (FTO or AZO), a current-limiting effect, a "rollover", is clearly visible. This rollover visible on the $I-V$ curves of bare TCO has disappeared after $\mathrm{In}_{2} \mathrm{O}_{3}$ deposition above the TCO. However it can be seen that the open circuit voltage $V_{o c}$ stays quite small. Therefore, in order to improve the $V_{\text {oc }}$ we have introduced a $3 \mathrm{~nm}$ thick $\mathrm{MoO}_{3}$ buffer layer at the interface $\operatorname{In}_{2} \mathrm{O}_{3}$ /organic material. Fig. 5 and Table 1 show that
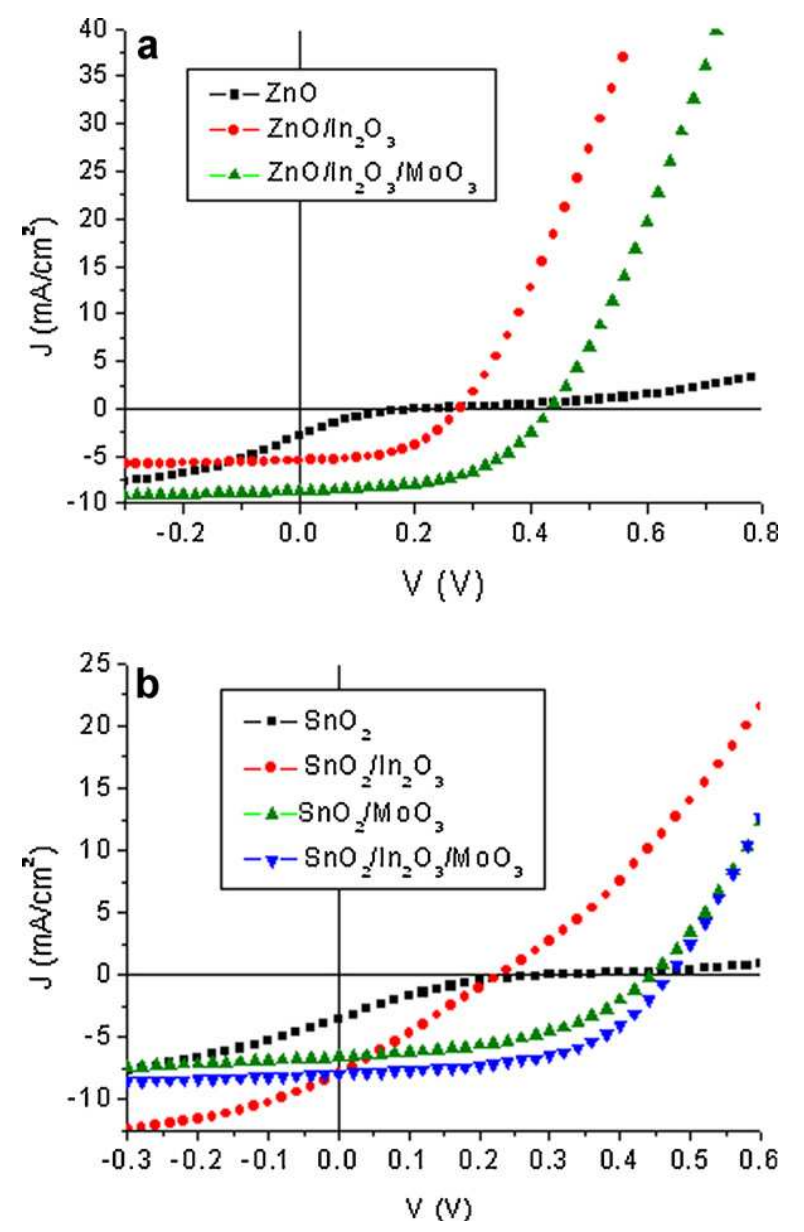

Fig. 5. (a) Typical $J-V$ characteristics of Anode $/ \mathrm{CuPc} / \mathrm{C}_{60} / \mathrm{BCP} / \mathrm{Al}$ structure, with Anode $=\mathrm{ZnO}(\boldsymbol{\square}), \mathrm{ZnO} / \mathrm{In}_{2} \mathrm{O}_{3}(\bullet)$ and $\mathrm{ZnO} / \mathrm{In}_{2} \mathrm{O}_{3} / \mathrm{MoO}_{3}$ (४), under illumination of AM1.5 solar simulation $\left(100 \mathrm{~mW} / \mathrm{cm}^{2}\right)$. (b) Typical $J-V$ characteristics of anode $/ \mathrm{CuPc} / \mathrm{C}_{60} / \mathrm{BCP} / \mathrm{Al}$ structure, with anode $=\mathrm{SnO}_{2}(\boldsymbol{\bullet}), \mathrm{SnO}_{2} / \mathrm{In}_{2} \mathrm{O}_{3}$ (•), $\mathrm{SnO}_{2} / \mathrm{MoO}_{3}(\boldsymbol{\Delta})$ and $\mathrm{SnO}_{2} / \mathrm{In}_{2} \mathrm{O}_{3} / \mathrm{MoO}_{3}(\boldsymbol{\nabla})$, under illumination of AM1.5 solar simulation $\left(100 \mathrm{~mW} / \mathrm{cm}^{2}\right)$.
Table 2

Properties of the surface of the anode. The total surface tension and corresponding components, pol for polar component and disp for dispersion component are given with the polarity $\chi_{\mathrm{p}}$.

\begin{tabular}{lclll}
\hline Sample & Disp $(\mathrm{mN} / \mathrm{m})$ & Pol $(\mathrm{mN} / \mathrm{m})$ & $\begin{array}{l}\text { Total surface } \\
\text { tension }(\mathrm{mN} / \mathrm{m})\end{array}$ & $\chi_{\mathrm{p}}$ \\
\hline $\mathrm{AZO}$ & 8.8 & 45 & 53.8 & 83.6 \\
$\mathrm{AZO} / \mathrm{In}_{2} \mathrm{O}_{3}$ & 7.8 & 52.5 & 60.3 & 87.1 \\
$\mathrm{FTO}$ & 13.8 & 35.5 & 49.3 & 72 \\
$\mathrm{FTO} / \mathrm{In}_{2} \mathrm{O}_{3}$ & 6.2 & 58.1 & 64.3 & 90.4 \\
\hline
\end{tabular}

the $\mathrm{MoO}_{3}$ film improves significantly $V_{\mathrm{oc}}$, and therefore the efficiency $\eta$ of the OPV cells. We have also probed $\mathrm{FTO} / \mathrm{MoO}_{3}$ anodes. The best results achieved are reported in Fig. 5, while in Table 1 the results correspond to averaged measurements issued from different batches of OPV cells. If the best efficiency is obtained with the trilayers anode $\mathrm{FTO} / \mathrm{In}_{2} \mathrm{O}_{3} / \mathrm{MoO}_{3}$, it can be seen that, in the case of the averaged results of Table 1 , roughly similar performances are achieved whatever the anode structure: $\mathrm{FTO} / \mathrm{In}_{2} \mathrm{O}_{3} / \mathrm{MoO}_{3}$ or $\mathrm{FTO} / \mathrm{MoO}_{3}$. This result shows that $\mathrm{MoO}_{3}$ is necessary for achieving good anode/electron donor interface, even in the presence of a fresh $\mathrm{In}_{2} \mathrm{O}_{3}$ thin film.

The small values of $V_{\mathrm{oc}}$, when the TCO anode is covered by a thin $\mathrm{In}_{2} \mathrm{O}_{3}$ layer, can arise from small shunt resistance, $R_{\text {sh }}$, value and through traps and poor band matching at the anode interface. Small $R_{\mathrm{sh}}$ value, issued from the presence of pin-holes and/or peak effects (roughness), which short circuit the OPV cells, induces strong dark current and small $V_{\mathrm{oc}}$ under illumination. About the band structure, indeed, it has been shown that the presence of the rollover effect in the $I-V$ curves could be attributed to the presence of an opposite diode at the interface anode/organic material, which decreases the $V_{\text {oc }}$ value [16].

In order to understand the different behaviours with the original anode structures, we have conducted complementary studies on the anodes, using scanning electron microscopy, atomic force microscopy and contact angle measurements.

First of all, it should be noted that the presence of a rollover effect in the $I-V$ curves, when bare AZO or FTO are used, should be attributed to the presence of an opposite diode at the interface anode/organic material. This barrier can be suppressed by better band adjustment. Therefore, the disappearance of the rollover in the $I-V$ curves can be attributed to a better band matching induced by the presence of the thin $\operatorname{In}_{2} \mathrm{O}_{3}$ layer, since the work function measured in room air by a Kelvin probe is, at least, $0.2 \mathrm{eV}$ larger than that of $\mathrm{SnO}_{2}$.

Results of the complementary studies are shown in Figs. 2 and 6. The example of FTO microphotographies with and without $\operatorname{In}_{2} \mathrm{O}_{3}$ is shown in Fig. 2. If there is no strong modification of the morphology of the anode after $\operatorname{In}_{2} \mathrm{O}_{3}$ deposition, small bright spots are visible, randomly distributed on the film surface. A similar result has been achieved with AZO. These results are corroborated by the AFM study (Fig. 6), as a matter of fact, there is some increase of the rms after $\mathrm{In}_{2} \mathrm{O}_{3}$ deposition. For instance, there is an increase of $35 \%$ of the rms in the case of $\mathrm{ZnO}\left(\mathrm{ZnO} \mathrm{rms}=1.67\right.$ to $\mathrm{ZnO} / \mathrm{In}_{2} \mathrm{O}_{3}$ rms $=2.27$ for $\mathrm{ZnO}$ ).

As seen in Table 2, the deposition of a thin $\mathrm{In}_{2} \mathrm{O}_{3}$ thin film onto AZO or FTO electrode increases sensibly the surface energy of the anode. It has already been reported that the increase of surface energy would provide a better adhesion of organic film to the substrate. Moreover higher surface energy of the anode is beneficial to a smooth growth of the organic film [17].

From the above studies it can be deduced that the thin $\mathrm{In}_{2} \mathrm{O}_{3}$ layer improves the properties of the interface FTO or AZO anode/CuPc through a better band matching and higher surface energy, while there is some degradation of the anode surface morphology. However there is no obvious reason for the small $V_{\mathrm{oc}}$ of 

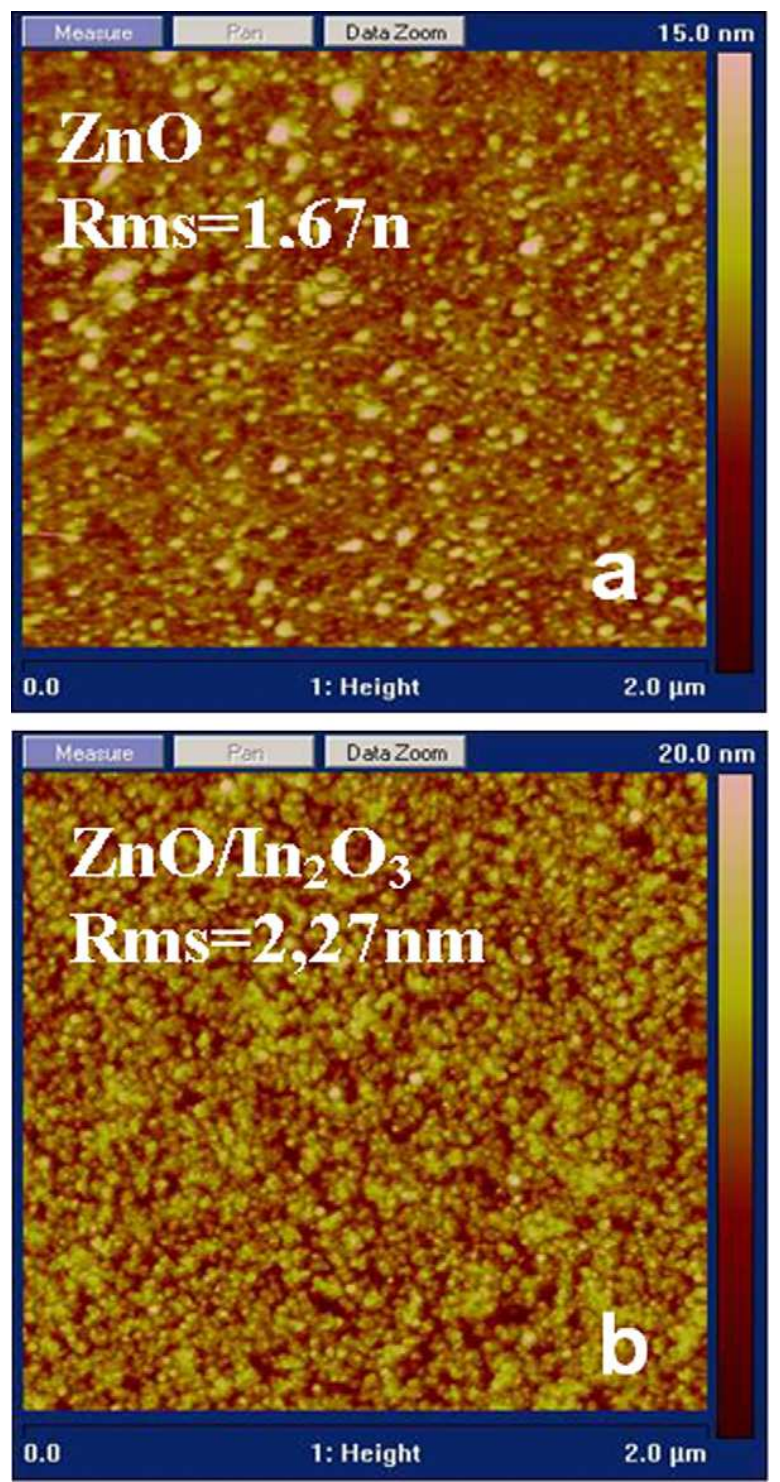

Fig. 6. TM-AFM images (a) of $\mathrm{ZnO}$ thin films and of (b) $\mathrm{ZnO} / \mathrm{In}_{2} \mathrm{O}_{3}$.

the cells using $\mathrm{TCO} / \mathrm{In}_{2} \mathrm{O}_{3}$ bilayers as anode. Therefore, it appears that, more probably, there are different causes, which converge to lower the performances of cells, causes which taken individually, would not justify the limited performances obtained. Lowering of $V_{\text {oc }}$ values can arise from TCO surface peaks, which short-circuit the PV cell and decrease the $R_{\mathrm{sh}}$. Also, the maximum $\Phi_{\mathrm{M}}$ value possible with reactive evaporation of $\operatorname{In}_{2} \mathrm{O}_{3}$ being inferior to $5 \mathrm{eV}$, the band matching improvement is not optimum, since the $\mathrm{HOMO}$ of $\mathrm{CuPc}$ is $5.2 \mathrm{eV}$.

Indeed, we have seen that, the roughness of the bilayer is slightly, but significantly higher than that of the TCO alone. In order to estimate the influence of the anode roughness modification on the shunt resistance value of the cells we have calculated the series, $R_{\mathrm{S}}$, and shun, $R_{\mathrm{sh}}$, resistances of the OPV cells. The equivalent circuit commonly used to interpret the characteristics of solar cell consists of current photogenerator connected in parallel with a diode, which represents the $I-V$ characteristics under dark conditions, while parasitic series and shunt resistances are represented by $R_{\mathrm{S}}$ and $R_{\mathrm{sh}}$ respectively [18]. The slopes at the short circuit point and at the open circuit voltage of the electrical cells characteristics are the inverse values of the shunt resistance $\left(R_{\mathrm{sh}}\right)$ and the series resistance $\left(R_{\mathrm{S}}\right)$ of the equivalent circuit scheme of a solar cell respectively [19].
Table 3

Series $\left(R_{\mathrm{S}}\right)$ and shunt resistance $\left(R_{\mathrm{Sh}}\right)$ of OPV cells using different anodes.

\begin{tabular}{lcc}
\hline Anode & $R_{\mathrm{sh}}(\Omega)$ & $R_{\mathrm{s}}(\Omega)$ \\
\hline FTO & 526 & 4960 \\
FTO $/ \mathrm{In}_{2} \mathrm{O}_{3}$ & 345 & 270 \\
FTO $/ \mathrm{In}_{2} \mathrm{O}_{3} / \mathrm{MoO}_{3}$ & 4215 & 136 \\
FTO $/ \mathrm{MoO}_{3}$ & 3046 & 176 \\
\hline
\end{tabular}

For instance, using the $J-V$ characteristics of Fig. $5 \mathrm{~b}$, the estimated values of $R_{\mathrm{S}}$ and $R_{\mathrm{sh}}$ are presented in Table 3. In the case of FTO, it can be seen that the value of $R_{\mathrm{S}}$ is very high, while the $R_{\mathrm{sh}}$ value is quite small. The introduction of a thin $\mathrm{In}_{2} \mathrm{O}_{3}$ film induces a strong decrease in $R_{\mathrm{S}}$ but also a small decrease in $R_{\mathrm{sh}}$, which explains the limited improvement of the cells performances and the small $V_{\mathrm{oc}}$ value. The introduction of the $\mathrm{MoO}_{3}$ buffer layer induces a strong decrease in $R_{\mathrm{S}}$ and increase in $R_{\mathrm{sh}}$, which explains the improvement of the cells performances. The $\mathrm{MoO}_{3}$ film being no conductive it allows the increase of $R_{\mathrm{sh}}$, while it permits a better band matching, which decreases the series resistance.

Therefore, the necessity of an insulating buffer layer can be justified by the roughness increase induced by the thin ITO film, which can partly short circuit the OPV cells, and the limited band matching at the anode interface.

\section{Conclusion}

It is well known that ITO gives better results than AZO or FTO when used as anode in organic optoelectronic devices. One of the main reasons of this, is that the work function of ITO is higher than that of AZO and FTO. We show that the deposition of a thin film $(5 \mathrm{~nm})$ of $\mathrm{In}_{2} \mathrm{O}_{3}$ onto the TCO allows improving the OPV cells performances. However the cells efficiency stays smaller than expected due to small $V_{\text {oc }}$ values. It is shown that if this thin $\mathrm{In}_{2} \mathrm{O}_{3}$ film increases the anode surface energy and therefore improves the interface band matching, the work function of the $\operatorname{~nn}_{2} \mathrm{O}_{3}$ stays smaller than the HOMO value of the CuPc and it increases the surface roughness of the anode, both properties which can justify the small $V_{\mathrm{oc}}$ value measured. The presence of a thin $\mathrm{MoO}_{3}$ insulating film allows overcoming these difficulties by giving a real band matching at the interface and increasing the shunt resistance of the cells.

\section{References}

[1] J.C. Bernède, Organic photovoltaic cells: history, principle and techniques, J. Chilean Chem. Soc. 53 (2008) 1549-1564.

[2] Y. Park, V. Choong, Y. Gao, B.R. Hsieh, C.W. Tang, Effect of plasma treatment on the performance of organic electroluminescente devices, Appl. Phys. Lett. 68 (1996) 2699-2701.

[3] C.-H. Wang, W.C.H. Choy, Efficient hole collection by introducing ultra-thin UV-ozone treated Au in polymer solar cells, Sol. Energy Mater. Solar Cell 95 (2011) 904-908.

[4] J. Park, H. Min Kim, D. Wook Kim, J. Sun Choi, Effect of gate electrode work function on electrical characteristics of pentacene-based field-effect devices, Appl. Phys. Lett. 97 (2010) 093301.

[5] C.N. Li, C.Y. Kwong, A.B. Djurisic, P.T. Lai, P.C. Chui, W.K. Chan, S.Y. Liu, Improved performance of OLEDs with ITO surface treatments, Thin Solid Films 477 (2005) 57-62.

[6] A. Klein, C. Körber, A. Wachau, F. Säuberlich, Y. Gassenbauer, S.P. Harvey, D.E. Proffit, T.O. Mason, Transparent conducting oxide for photovoltaic: manipulation of fermi level, work function and energy band alignment, Materials 3 (2010) 4892.

[7] T. Minami, Substitution of transparent conducting oxide thin films for indium tin oxide transparent electrode application, Thins Solid Films 516 (2008) 1314-1321.

[8] M. Owen, S. Son, K.-H. Yoo, D.B. Ahn, S.Y. Lee, Organic photovoltaic devices with Ga-doped ZnO electrode, Appl. Phys. Lett. 90 (2007) 033512.

[9] Q. Qiao, J. Beck, R. Lumpkin, J. Pretko, J.T. Mcleskey Jr., A comparison of fluorine tin oxide and indium tin oxide as the transparent electrode for $\mathrm{P}_{3} \mathrm{OT} / \mathrm{TiO}_{2}$ solar cells, Sol. Energy Mater. Solar Cells 90 (2006) 1034-1040. 
[10] M. Morsli, C. Amory, A. Bougrine, L. Cattin, J.C. Bernède, Current voltage $(I-V)$ studies of Mo/g- $\mathrm{In}_{2} \mathrm{Se}_{3} / \mathrm{ZnO}:$ Al diode structures, J. Phys. D: Appl. Phys. 40 (2007) 7675-7681.

[11] R.F. Salzman, J. Xue, B.P. Rand, A. Alexander, M.E. Thompson, S.R. Forrest, The effect of copper phthalocyanine purity on organic solar cell performance, Org. Electron. 6 (2005) 242-246

[12] A. Latef, J.C. Bernède, Study of the thin film interface aluminium-tellurium, Phys. Status Solidi (a) 124 (1991) 243-252.

[13] Y. Berredjem, N. Karst, A. Boulmokh, A.H. Gheid, A. Drici, J.C. Bernède, Optimisation of the interface organic material/aluminium of $\mathrm{CuPc} / \mathrm{C}_{60}$ based photovoltaic cells, Eur. Phys. J.: Appl. Phys. 40 (2007) 163-167.

[14] C.D. Wagner, W.M. Riggs, L.E. Davis, J.F. Moulder, G.E. Muilberg, Hnadbook of X-rays Photoelectron Spectroscopy, PerkinElmer, Eden Prairie MN, 1979.

[15] L. Cattin, F. Dahou, Y. Lare, M. Morsli, R. Tricot, S. Houari, A. Mokrani, K. Jondo, A. Khelil, K. Napo, J.C. Bernède, $\mathrm{MoO}_{3}$ surface passivation of the transparent anode in organic solar cells using ultra-thin films, J. Appl. Phys. 105 (2009) 034507.

[16] B. Kouskoussa, M. Morsli, K. Benchouk, G. Louarn, L. Cattin, A. Khelil, J.C. Bernède, On the improvement of the anode/organic material interface in organic solar cells by the presence of an ultra-thin gold layer, Phys. Status Solidi (a) 206 (2009) 311-315.

[17] Z.H. Huang, X.T. Zeng, X.Y. Sun, E.T. Kang, J.Y.H. Fuh, L. Lu, Influence of plasma treatment of ITO surface on the growth and properties of hole transport layer and the device performance of OLEDs, Org. Electron. 9 (2008) 51-62.

[18] B. Mazhari, An improved solar cells circuit model for organic solar cells, Sol. Energy Mater. Solar Cells 90 (2006) 1021-1033.

[19] B. Brousse, B. Ratier, A. Moliton, Vapour deposited solar cells based on CuPc-C 60 single heterojunction: optimizattion of the deposition process, Synth. Met. 147 (2004) 293-298. 